\title{
English Teachers' Understanding of the 2013 Curriculum
}

\author{
Endang Darsih \\ Department of English Education, Faculty of Teacher Training and Education, \\ The University of Kuningan, Indonesia \\ Email: she_n2@yahoo.com
}

\begin{abstract}
This study focused on English teachers' understanding of the 2013 curriculum at five targeted junior high schools in Kuningan, West Java. It involved sixteen teachers using mixmethod design. Since teachers are the key people who are interpreting the planned curriculum and giving life to it in the language classroom by means of their instructional and evaluation strategies, their understanding toward the curriculum is important to be noticed. Teachers' good understanding of the 2013 curriculum becomes the important factor in implementing the 2013 curriculum successfully. This study revealed that English teacher's understanding of the 2013 curriculum is quite close to the basic principles of the curriculum. Teachers seem to have a comprehensive understanding on the elements of the curriculum such as general concept of the curriculum, general concept of the 2013 curriculum, teaching and learning process as well as assessment based on the 2013 curriculum, but they are less knowledgeable in understanding the rationale and the changing elements. The 2013 curriculum also provides some benefits for teachers. However, teachers need to improve their understanding on implementing scientific approach and authentic assessment, since they tend to use conventional method such as lecturing.
\end{abstract}

Keywords: Teachers' Understanding, The 2013 Curriculum

\section{INTRODUCTION}

Curriculum is the foundation of teaching and learning process. It is one of the important factors involved in teaching and learning process and it is the teacher who is the principle agent of curriculum development (Nunan, 1988).

Developing curriculum is a comprehensive and multidimensional process, in which curriculum is planned, designed and then implemented in the classrooms (Oliva, 2009; Ornstein \& Hunkins, 2009). In curriculum development, teachers' role is of utmost importance. Teachers' involvement and knowledge of the orientation of the curriculum give them a chance to exploit the current sources at their best for optimum results. In line with that, Marsh (2009) states that the active participation of teachers in curriculum planning is limited and teachers are regarded as curriculum implementers whose role is to adapt official curriculum to their classroom.

In 2013, the government decided to try out the new designed curriculum, the 2013 curriculum. 6.410 schools consisting 2.598 elementary schools, 1.521 junior high schools, 1.270 senior high schools, and 1.021 vocational high schools have participated in this try out implementation (http://kemdikbud.go.id/kemdikbud/berita/1309).
As suggested by the ministry of education that the reason to justify such implementation of this new curriculum is to restore character education and improve students' creative thinking. Students are required to be more active, creative, and innovative. Besides that, the character building is integrated in all subjects.

However, the government's decision to introduce the 2013 curriculum has met some mixed reactions. Those who supported are upbeat that the new curriculum better suit the future challenges and ease the burdens on students and teachers, while those who objected are worried about the lack of focus on the curriculum due to the merging of some subjects. The result of interview with some junior high school teachers in Kuningan revealed that most of teachers were not ready to implement the 2013 Curriculum in terms of books, assessment systems, teachers' training, teachers' mentoring and Principals training. Although they have been trained, many teachers are still confused. They are afraid they would not have enough time to learn and make preparations since they still have yet to be informed about details in the new curriculum.

As a result, in 2014 the Minister of Culture and Primary and Secondary Education, Anies Baswedan has ordered the pilot project schools to return to the 2006 curriculum and/or to continue to implement the 2013 curriculum. His decision was actually confusing since there are two curricula implemented in one school at the same time. Regarding this decision, different reactions and opinions are emerged from the society, schools and teachers. A big question is also raised whether this decision is based on the fact that most schools and teachers are more prepared to implement the 2006 curriculum. As we know that teachers are the key people who are interpreting the planned curriculum and giving life to it in the language classroom by means of their instructional and evaluation strategies. A successful curriculum and examination system involves all stakeholders to create its ownership. The 2013 curriculum is generally planned without consulting the end users i.e. teachers, who therefore, cannot deliver it effectively. Therefore, teachers' lack understanding of the 2013 curriculum becomes a serious problem in implementing the 2013 curriculum successfully. Teachers' lack understanding also influences the way they teach, the way they assess their students and conduct the teaching and learning process. As a result, it is found that teachers are still difficult to create a student-centered classroom and students are not motivated to participate actively in the classroom. 
The issue of changing curriculum to the 2013 curriculum has been popular among educators in Indonesia. However, only few have studied on the 2013 English curriculum (Prisilya (2014), Shofiya (2014), Matra (2014), Kusumaningrum (2014), Muniroh (2014), Syarifah \& Ningsih (2014), Stepani \& Apriyani (2014), Handayani (2014), Rohadi, (2014).

Hence, this study intends to portray English teachers' understanding of the 2013 curriculum in the teaching of English in junior high schools in Kuningan as well as benefits and challenges faced by the teachers after two-year of the implementation of this curriculum.

\section{RESEARCH METHODOLOGY}

This study employed mixed-methods; quantitative data were collected first through survey using Thurstone scale questionnaires, then qualitative data using interview were gathered. To get in-depth information, then, qualitative method was also applied to support the quantitative data. The researcher conducted interview in collecting the data. This kind of data collection can also be used to investigate person's perspective (Patton, 1990 in Merriam, 1998:72). The small numbers of participants who were interviewed were chosen based on purposive sampling. Therefore, this study has the same characteristics as qualitative research. (Kitao and Kitao, 2002; Silverman, 2005; Sugiono, 2007; Moleong, 2007; Gall, et al, 2005).

The research was conducted in five state junior high schools in Kuningan as "pilot project" schools of the 2013 Curriculum, namely SMPN 1 Kuningan with five English teachers, SMPN 4 Kuningan with three English teachers, SMPN 5 Kuningan with 1 English teacher, SMPN 1 Luragung with five English teachers, and SMPN 3 Luragung with two English teachers.

\section{RESEARCH FINDINGS AND DISCUSSIONS}

This section displays the research findings that are found in this study and also demonstrates how they correspond to the research questions and theoretical foundations. The findings are obtained from questionnaires and supported by interview data. The data from both questionnaires and interview are classified based on the research questions which are broken down into three categories: EFL teachers' understanding of the 2013 curriculum, benefits felt by EFL teachers in implementing the 2013 curriculum, and challenges faced by EFL teachers in implementing the 2013 curriculum.

\section{1) EFL Teachers' Understanding of the 2013 Curriculum}

The results from questionnaires and interview revealed that the participants have various understanding toward curriculum. In this case, the participants viewed the meaning of curriculum from different angles. However, their definitions are in line with definition from Board of National Educational Standard, in Indonesia Badan Standar Nasional Pendidikan or BSNP (2006:5) namely: "Kurikulum adalah seperangkat rencana dan pengaturan mengenai tujuan, isi dan bahan pengajaran serta cara yang digunakan sebagai pedoman penyelenggaraan kegiatan pembelajaran untuk mencapai tujuan pendidikan tertentu". It means that curriculum is a set of plans and rules which deal with goals, contents, teaching materials, and methods used as guidance in the teaching-learning process in order to achieve certain educational goals. Besides that, the participants viewed curriculum firstly as a set of materials or lesson for students; this also indicates that they seem to have a good understanding on this point because what they had mentioned refers to the definition of curriculum as the body of subjects or the subject matters set out by teachers for students to cover (Tanner and Tanner, 1995:151). Secondly, as a plan for teaching and learning; it is in line with definition of curriculum by Taba (1962) as a plan for learning, or a general overall plan of the content or specific materials of instruction that the school should offer the student by way of qualifying him for graduation or certification or for entering into a professional or vocational field (Good, 1959, quoted in Connelly and Lantz, 1991:15). Thirdly, as a guideline for teaching; this also indicates that they have good understanding on this point because curriculum contains guidelines about what to teach, how to teach, and what are expected.

Regarding the definition of the 2013 curriculum, The Ministry of Education and Culture (Kemendikbud, 2012:10 in Srijono 2013:59) states that the 2013 curriculum is in fact the extension of SBC in several components. It is as a means of integrating value systems, knowledge and skills, as an orientation on developing the learners' competencies, as the changing of teaching-learning methodology towards teaching-learning process which gives priorities on the learning experiences through observing, inquiring, associating, and communicating, so as to enhance the values of competitiveness and build prime characters. The interview data found that all participants seem to have a comprehensive understanding on these points.

The main purpose of 2013 curriculum is to shape the individuals who are faithful in God, good in characters, confident, successful in learning, responsible citizen and positive contributors to the civilization (Ministry of Education and Cultures, 2012). Regarding this point, all of the participants also seem to have good understanding. They all know exactly the purpose of the 2013 curriculum. They are sure and able to answer the question dealing with purpose of the 2013 curriculum correctly. It implies that all of the participants are knowledgeable not only in this matter but also in understanding the structure of the 2013 curriculum, assessment and teaching learning process based on the 2013 curriculum. The responses from interview and questionnaires indicate that the participants are very knowledgeable and almost all of the answers are in line with what had been mentioned in Permendikbud No. 81a Tahun 2013. However, the participants are less knowledgeable in understanding the rationale and the changing elements of the 2013 curriculum as well. 


\section{2) Benefits of the 2013 Curriculum Implementation}

The results from questionnaires and interview revealed that there are five benefits embedded in the implementation of the 2013 curriculum. The first, 2013 curriculum is able to improve the quality of learners, not only of their cognitive aspects, but also of their characters, skills, and attitudes due to the integrated character education in the learning process. The second one, the teachers' teaching load is not too heavy, especially the nature of the student-centered learning, is a convenience for teachers because students find and apply his own ideas, so they use their own learning strategies for learning. This of course can enhance the active participation of the students and can increase the potential of the students. The third one, the book provided by the government helps teachers much, because it becomes their guidelines in teaching. The fourth, it improves teachers' motivation in teaching. In 2013 curriculum, teachers act as facilitator and motivator, so they have to be more creative and smarter in choosing the learning activities that motivate students to participate actively in the classroom. The last, assessment based on the 2013 curriculum is fair since all aspects of students are assessed.

\section{3) Challenges of the 2013 Curriculum Implementation}

Related to the challenges, the questionnaires data showed that there are several challenges such as in applying scientific approach, authentic assessment and in designing lesson plan. Scientific approach becomes challenge for teachers because they tend to use conventional method such as lecturing, meanwhile, teachers' mastery of technology and information is also limited. Authentic assessment also becomes challenge for teacher because it is still difficult to implement. The questionnaires data also showed that it is not an easy task to design a lesson plan. The English teachers still considered that designing a lesson plan prior to teaching is a burden. Concerning the challenges of 2013 curriculum implementation, the interview data showed that there are five challenges. First, it is quite hard to apply authentic assessment, because teachers tend to assess final product of students competency. Second, teachers need to adapt with the learning revolution based on 2013 curriculum. The 2013 curriculum emphasizes a modern pedagogical dimension in the learning process by using scientific approach. Scientific approach covers five steps namely observing, questioning, associating, experimenting, and networking. Third, the shortage of time makes it hard for teachers to provide or improve students' competency by giving them exercises and opportunity to practice and speak English. The fourth, it is challenging to motivate students to be active speaking English because they usually speak their mother tongue. It takes time to create students-centered classroom. The last challenge is in designing lesson plans; teachers still find difficulties in choosing teaching method, teaching media and integrating character education.

\section{REFERENCES}

BSNP. (2006). Panduan Penyusunan Kurikulum Tingkat Satuan Pendidikan Jenjang Pendidikan Dasar dan Menengah. Jakarta: Badan Nasional Standar Pendidikan.

Connelly, F. M., and Lantz, O. C. (1991). Definitions of Curriculum: An Introduction. In A. Lewy (Ed.), The International Encyclopaedia of Curriculum, (pp. 1518). Pergamon Press, New York.

Gall, M. D, et al. (2003). Educational Research: an Introduction. USA: Perason Education, Inc.

Handayani, V. (2014). Teaching English as a Local Content in Primary Education in The Context of 2013 Curriculum. Proceeding International Conference on Applied Lingusitics in Bandung.

Kitao, S. K., \& Kitao, K. (2002). Approaches to Social Science Research: Communication and Languge Teaching/Learning. Tokyo: EICHOSHA ltd.

Kusumaningrum, R. S. (2014). The 2013 English Curriculum: Prospects and Challenges. Proceedings the $61^{\text {st }}$ TEFLIN International Conference 2014 in Solo.

Marsh, C. (2009). Key concepts for understanding curriculum. London: Routledge/Taylor\&Francis Group.

Matra, D. S. (2014). The English Teachers' Perceptions toward School-based Curriculum (SBC) and 2013 Curriculum; Complaints, Comparisons and Contrasts (An Investigation on English Teachers" Perceptions in Pekalongan). Proceedings the $61^{\text {st }}$ TEFLIN International Conference 2014 in Solo.

Merriam, S. B. (1998). Qualitative Research and Case Study Applications in Education. San Fransisco: Jossey-Bass Inc.

Moleong, L J. (2007). Metodologi Penelitian Kualitatif. Bandung: PT Remaja Rosdakarya.

Muniroh, S. (2014). Challenges and Recommendations on the Implementation of 2013 Curriculum. Proceedings the $61^{\text {st }}$ TEFLIN International Conference 2014 in Solo.

Nunan, D. (1988). The Learner-Centred Curriculum. Britain: Cambridge University Press.

Oliva, P. (2009). Developing the curriculum (7th ed.). USA: Allyn and Bacon.

Ornstein, A. C., \& Hunkins, F. P. (2009). Curriculum: Foundations, principles, and issues (4th Ed.). USA: Pearson Education.

Prisilya, A. (2014). Which One is Better; KTSP (Schoolbased Curriculum) or 2013 English Curriculum?. Proceedings the $61^{\text {st }}$ TEFLIN International Conference 2014 in Solo.

Rohadi, T. (2014). Empowering Students' Social Intelligence Through Merging Critical Literacy Into 2013 Curriculum. Proceeding International Conference on Applied Lingusitics in Bandung. 
Shofiya, A. (2014). Teachers" Responses toward 2013 Curriculum: After a Year of Implementation. Proceedings the $61^{\text {st }}$ TEFLIN International Conference 2014 in Solo.

Silverman, D. (2005). Doing Qualitative Research. London: SAGE Publications Ltd.

Stepani, M \& Apriyani, D. J. (2014). Teachers' Perception on 2013 Curriculum in English Language Teaching. Proceeding International Conference on Applied Lingusitics in Bandung.

Syarifah, F. E \& Ningsih, R.P. (2014). From KTSP to 2013 Curriculum: Teachers' Perception and Implementation. Proceeding International Conference on Applied Lingusitics in Bandung.

Srijono, D. (2013). Chapter 3 Principles of English Instructional Design - Modul PLPG English Language Teaching and Learning Theory and Practice. Badan Pengembangan Sumber Daya Manusia. Pendidikan Kebudayaan dan Penjaminan Mutu Pendidikan (BPSDMP-PMP). Indonesia.

Sugiono. (2007). Metode Penelitian Pendidikan. Bandung: Alfabeta.

Taba, H. (1962). Curriculum Development: Theory and Practice. Harcourt Brace, New York.

Tanner, D., and Tanner, L. N. (1995). Curriculum Development: Theory into Practice (3rd Edition). Merrill/Prentice-Hall, Englewood Cliffs, NJ. 